\title{
PELATIHAN PEMBUATAN BUKU AJAR BERBASIS LIMBAH DI GUGUS LARASATI GUNUNGPATI SEMARANG
}

\author{
Umar Samadhy, Jaino, Mujiyono \\ Fakultas Ilmu Pendidikan, Universitas Negeri Semarang \\ Email: umarsamadhy@mail.unnes.ac.id
}

\begin{abstract}
Devotion to the purpose of this society is to provide training for the management of newspaper paper waste, the magazine of a new teaching material. Skills and techniques employed by teachers are to integrate and make montage techniques useful and useful for the use of ja drawings from waste on paper, and are given information on the learning of Targdisetkolahkhususdasaricapymeng.i, and the management of waste is damaged with the earth, as a form of conservation and environmental conservation which are programmed by the State University. In addition, the teaching materials (drawing), provide them with the effectiveness of the lesser deficiencies of learning in the students. It is hoped that the dedication of improvement in the classroom, ajardan correlates positi students. Digunakanpelatihan methods, practices, danpendadalampinganh membua bukuajar with limbahkan mengelola.Pertemuan paper 15 times, three meetings in it do for the introduction and evaluation of activities, as well as much knowledge as pendukung12. meetings, participants manage with waste paper technique for montage used as instructional materials, in accordance with learning materials Evaluation of achievement in sekoahl by way of assessment of textbook Implementation of service devoted on Saturday, in Larasati routine event in Gunungpati Semarang. All over the past 8 months, producing outcomes, yait creating teaching materials, journals, and publications
\end{abstract}

Keyword: Waste paper, montase technique, teaching materials, primary school teachers, gugus larasati

\begin{abstract}
Abstrak. Pengabdian kepada masyarakat ini bertujuan secara umum untuk memberikan pelatihan mengelola limbah kertas koran, majalah, dan buku ajar lama, menjadi sebuah bahan ajar baru dengan teknik montase. Keterampilan yang akan didapatkan oleh guru adalah memadukan dan membuat bahan ajar dengan teknik montase. Teknik montase merupakan penggunaan dan pemanfaatan gambar jadi (bersumber dari limbah) yang dikomposisikan dengan media gambar (pewarna), ditempelkan di atas kertas, dan diberikan keterangan atau materi ajar yang disesuaikan dengan pembelajaran di sekolah dasar. Target khusus yang ingin dicapai, menghasilkan guru yang berbakat dan terampil menghasilkan buku ajar dengan mengelola limbah kertas. Dengan pengelolaan limbah kertas dengan baik, menekan elemen perusak bumi, sebagai wujud konservasi dan peduli lingkungan yang diprogramkan oleh Universitas Negeri Semarang. Selain itu, bahan ajar dengan tampilan visual (gambar), memberikan efektifitas tersampainya materi pembelajaran lebih tinggi pada para peserta didik. Diharapkan, pengabdian ini memberikan dampak terhadap peningkatan bahan ajar di kelas, dan berkorelasi positif atas hasil belajar peserta didik. Metode yang digunakan adalah pelatihan, praktik, dan pendampingan membuat buku ajar dengan mengelola limbah kertas. Pertemuan akan diselenggarakan sebanyak 15 kali, di dalamnya terdapat 3
\end{abstract}


pertemuan dilakukan untuk memberikan pengantar dan evaluasi kegiatan, serta penguatan keterampilan dengan ilmu pengetahuan pendukung. Sebanyak 12 pertemuan, peserta pelatihan didampingi mengelola limbah kertas dengan teknik montase untuk dijadikan sebagai bahan ajar, sesuai dengan materi pembelajaran di sekolah dasar. Evaluasi ketercapaian materi dengan cara penilaian buku ajar yang dihasilkan oleh peserta pelatihan. Pelaksaan pengabdian di hari Sabtu, dalam acara rutin KKG yang diselenggarakan oleh Gugus Larasati di Gunungpati Semarang. Seluruh kegiatan pengabdian dilaksanakan selama 8 bulan, menghasilkan luaran, yaitu: peningkatan keterampilan guru membuat bahan ajar, jurnal, dan publikasi di media massa.

Kata Kunci: Limbah kertas, teknik montase, bahan ajar, guru SD, gugus larasati

\section{PENDAHULUAN}

Buku ajar merupakan hal penting yang menjadi sumber pembelajaran bagi peserta didik. Tindakan utama yang akan dilakukan dalam pelatihan mengacu pada keterbatasan buku ajar dengan tampilan visual di Gugus Larasati. Buku ajar dengan tampilan visual menarik, akan meningkatkan daya pikir dan imajinasi anak untuk semakin fokus pada pembelajaran yang menyenangkan. Bacon (dalam Tarigan) mengemukakan bahwa "buku teks (ajar) buku dirancang buat penggunaan di kelas, dengan cermat disusun dan disiapkan oleh para pakar atau ahli dalam bidang tertentu dan dilengkapi dengan sarana sarana pengajaran yang sesuai dan serasi”.

Di Gugus Larasati Kecamatan Gunungpati memiliki 9 anggota, yaitu: SDN Plalangan 01, SDN Plalangan 02, SDN Plalangan 03, SDN Plalangan 04, SDN Pakintelan 01, SDN Pakintelan 02, SDN Pakintelan 03, SDN Sumurrejo 01, dan SDN Sumurrejo 02. Gugus Larasati mempunyai agenda rutin setiap bulan dalam acara Kelompok Kerja Guru (KKG). Materi dalam acara KKG di Gugus Larasati untuk wadah berbagi informasi terbaru dari dinas terkait, evaluasi pembelajaran, dan beberapa kali dilakukan pelatihan untuk peningkatan keterampilan mengajar bagi guru.
Keterampilan yang sering dilakukan adalah terkait untuk peningkatan kemampuan guru bidang informasi dan teknologi (kemampuan menguasai komputer untuk pembelajaran di kelas). Tim pengabdian dari Universitas Negeri Semarang (UNNES) bermitra dengan Gugus Larasati, akan dilaksanakan dalam acara $\mathrm{KKG}$.

Acara KKG merupakan wadah untuk memberikan keterampilan baru bagi guru di Gugus Larasati. Aktivitas yang selama ini dilakukan adalah mengatur jadwal guru sebagai narasumber dalam kegiatan KKG, dengan materi sesuai kesepakatan bersama. Kegiatan ini sudah positif dan memberikan informasi pembelajaran bagi guru lain. Tim pengabdi dari UNNES akan hadir dan bermitra dengan Gugus Larasati, sebagai narasumber dalam acara KKG tersebut. Materi yang diberikan kepada guru di Gugus Larasati adalah pemanfaatan limbah kertas, koran, majalan, dan buku ajar lama, untuk digunakan dan dibentuk menjadi sebuah buku ajar yang menarik, komunikatif, dan menyenangkan bagi anak. Sampah kertas dari koran, majalah, kalender, dan buku ajar lama cukup tinggi. Pengelolaan selama ini hanya dibakar atau dijual kiloan kepada pengepul. Hal ini masih kurang efisien. Pembuatan buku ajar berbasis limbah dengan teknik montase, merupakan alternatif 
peningkatan fungsi barang bekas dan menekan sampah yang merugikan lingkungan. Montase merupakan suatu karya seni dengan teknik menempel gambar gambar yang sudah ada dan dikombinasikan, sehingga membentuk suatu gambar baru dengan makna yang berbeda (Setiawan, dkk, 2016:88).

Kondisi lain yang diselesaikan adalah mencari alternatif murah untuk menciptakan buku ajar, menghasilkan guru kreatif dan bertanggung jawab atas karya cipta. Dengan gerakan literasi yang diprogramkan oleh pemerintah, kegiatan menciptakan buku ajar bertampilan visual menarik, akan mendorong minat baca dan belajar anak. Semakin banyak guru yang kreatif, besar kemungkinan akan semakin meningkatkan jumlah buku ajar berkualitas, sehingga diharapkan dapat berkorelasi positif dengan peningkatan hasil belajar siswa sekolah dasar. Diungkapkan oleh Valjataga dan Fiedler (Lecture Notes in computer Science Vol. 8523, 2014), "Literature Review on Etextbooks" menyatakan buku pelajaran menjadi praktik yang semakin penting dalam pendidikan formal. Persoalan prioritas yang diselesaikan dalam pengabdian ini, sebagai berikut.

1. Hambatan mengajar dengan terbatasnya buku ajar yang bersifat visual.

2. Penguatan keterampilan sumber daya guru dengan materi pelatihan menciptakan buku ajar.

3. Perencanaan dan pengelolaan limbah kertas dengan terencana baik, sehingga dapat mengurai pencemaran lingkungan.

4. Mendukung wawasan konservasi yang diprogramkan oleh UNNES.

Solusi dan target aktivitas dilakukan untuk menyelesaikan permasalahan mitra sesuai dengan prioritas, sebagai berikut.

1. Meningkatkan jumlah buku ajar berbasis pengelolaan limbah kertas, dengan teknik montase, sehingga memberi efek pengurangan limbah yang merugikan bagi lingkungan.

2. Target utama adalah peningkatan keterampilan pada sumber daya manusia, dalam hal ini adalah guru. Guru harus senantiasa kreatif dalam menyikapi keadaan peserta didik, mampu mengelola kelas menjadi pembelajaran yang menyenangkan. Untuk menciptakan kelas menyenangkan, salah satunya melalui buku ajar dengan tampilan visual menarik, yang dibuat sendiri. Buku ajar yang menyenangkan anak, akan meningkatkan hasil belajar peserta didik.

3. Memberikan informasi terbaru mengenai media pembelajaran berbasis limbah kertas, sehingga selain bermanfaat bagi pembelajaran di kelas, juga berdampak positif bagi lingkungan.

Menurut penelitian Eis Sukmana, Rena Lestari dan Ria Karno yang berjudul "Pengaruh Model Pembelajaran Langsung (Direct Instruction) disertai Media Gambar Terhadap Hasil Belajar Biologi Siswa Kelas VII SMP Negeri 1 Tambusai Utara". Hasil penelitian menunjukkan, bahwa terjadi peningkatan hasil belajar pada kelas eksperimen dan kelas kontrol karena hampir seluruh siswa sudah mampu mencapai nilai KKM 70. Hal ini dikarenakan pada kelas eksperimen yang mengikuti model Direct Instruction disertai media gambar lebih aktif dalam proses pembelajaran dibandingkan dengan siswa yang mengikuti pembelajaran konvensional. Nilai rata-rata kelas eksperimen sebesar 75,00 dan nilai ratarata kelas kontrol sebesar 61,32. Hasil ini menunjukan bahwa model pembelajaran langsung (Direct Instruction) efektif dalam meningkatkan hasil belajar siswa.

\section{METODE}


Metode pelaksanaan kegiatan dalam pengabdian Pelatihan Pembuatan Buku Ajar Berbasis Limbah di Gugus Larasati Gunungpati Semarang dijelaskan sebagai berikut.

\section{Persiapan} meliputi:

Tahap persiapan yang dilakukan

1. Observasi awal untuk identifikasi masalah, diketahui kebutuhan lapangan

\section{a. Tahap 1}

Para guru di Gugus Larasati menerima pendalaman materi buku ajar dan kelayakannya berdasarkan sumber tertentu. Kegiatan ini dilakukan 2 kali pertemuan. Pendalaman materi dipandang penting, untuk memberi pengetahuan dasar buku ajar, fungsi, dan manfaat; pemahaman teknik, alat, bahan, dan proses pengerjaan.

Kegiatan telah dilaksanakan dengan baik, dan mendapatkan respons positif dari para guru. Dalam kegiatan pendalaman materi pertemuan pertama, narasumber adalah Umar Samadhy, M.Pd, yang menyampaikan pembahasan tentang pembuatan bahan ajar dengan baik. Durasi penyampaian materi dilaksanakan selama 45 menit, diskusi atau pertanyaan dari peserta pelatihan sebanyak 15 menit. 60 menit terakhir digunakan untuk diskusi kelompok berdasarkan jumlah kelas di sekolah dasar, yaitu 1-6. Selama diskusi dibantu oleh Drs. Jainom, M.Pd, dan Mujiyono, M.Pd. Pertemuan ke-2 membahas persoalan kelayakan dan ketepatan bahan ajar, serta pembuatan bahan ajar berbasis limbah, disampaikan oleh Umar Samadhy, M.Pd, selama 45 menit, dilanjutkan dengan diskusi selama 15 menit. Setelah itu, peserta berdiskusi dalam kelompok kelas, sesuai dengan pertemuan sebelumnya. (mitra).

2. Penyusunan bahan/materi pelatihan dalam bentuk modul pelatihan pengelolan limbah kertas menjadi buku ajar di Gugus Larasati Gunungpati.

\section{Tahap Pelaksanaan Kegiatan}

Tahap pelaksanaan merupakan kegiatan pelatihan keterampilan, yang dibagi menjadi beberapa tahap, yaitu:

Beberapa kelemahan yang muncul adalah guru masih kurang berpengalaman mengatasi persoalan anak atau peserta didik yang suka mengganggu dalam proses pembelajaran. Hal ini diindikasikan bersumber dari bahan ajar yang kurang menarik, sehingga fokus dari peserta didik kurang optimal. Selain itu, persoalan yang muncul adalah bagaimana mengadaptasikan dan menyesuaikan bahan ajar nasional menjadi berbasis daerah, hal ini yang mendorong tidak tersampaikannya materi pembelajaran dengan optimal.

\section{Tahap 2}

Setelah pemahaman dan pengantar teori bahan ajar diberikan sebanyak 2 kali pertemuan. Selanjutnya, memberikan pelatihan dan pendampingan kepada guru di Gugus Larasati, dengan materi pengelolaan limbah kertas menjadi buku ajar direncanakan sebanyak 12 pertemuan. Peningkatan keterampilan pengelolaan limbah kertas menjadi buku ajar, dilakukan dengan cara memberikan materi dan keterampilan dalam bentuk pembelajaran langsung. Hal ini berdasarkan Suprijono (2015:65-66), bahwa model direct instruction atau pembelajaran langsung merupakan gaya mengajar guru terlihat aktif dalam memberikan isi pelajaran kepada peserta didik dan mengajarkannya secara 
langsung kepada seluruh kelas. Tim pengabdi sebagai guru yang mendampingi pembelajaran pengelolaan limbah menjadi buku ajar.

Pendekatan utama yang dilakukan menganut pada pandangan Suprijono (2015:66), bahwa pembelajaran langsung adalah modelling, berarti mendemonstrasikan suatu prosedur pembelajaran kepada peserta didik. Modelling mengikuti tahapan sebagai berikut.

1. Tim Pengabdi mendemonstrasikan perilaku yang hendak dicapai sebagai hasil

belajar. Proses ini merupakan aktivitas demo, dilakukan untuk memberikan contoh kepada peserta pelatihan. Contoh yang dimaksud adalah proses mengelola limbah kertas secara berurutan atau sistematis, sampai menghasilkan sebuah buku ajar, sesuai dengan perencanaan.

2. Tim Pengabdi mendemonstrasikan pembuatan buku ajar berbahan limbah kertas dengan cara yang jelas, terstruktur, dan berurutan, disertai penjelasan mengenai apa yang dikerjakan.

3. Peserta didik mengingat langkahlangkah yang diajarkan oleh guru, kemudian menirukan. Tahapan ini menunjukkan praktik membuat buku ajar dengan menggunakan limbah kertas yang dilakukan oleh peserta pelatihan.

\section{HASIL DAN PEMBAHASAN}

Pendampingan dan pelatihan materi Pembuatan Buku Ajar Berbasis Limbah dengan Teknik Montase dibutuhkan oleh guru di Gugus Larasati Gunungpati Semarang. Beberapa peserta mengeluhkan kurangnya pengetahuan dan pemahaman mengenai pembuatan buku ajar dan teknik kolase, korelasi buku ajar dengan profesi guru, dan arti penting peran buku ajar dalam memupuk kecintaan peserta didik terhadap pembelajaran yang berlangsung di kelas. Di mana kecintaan terhadap buku ajar atau pembelajaran yang berlangsung di kelas, memberikan motivasi positif bagi peserta didik, untuk terus maju, peduli terhadap lingkungan alam dengan memberdayakan ulang limbah kertas, dan penanaman kecintaan terhadap lingkungan sejak dini. Guru-guru belum menyadari secara sepenuhnya, bahwa pengelolaan limbah kertas dengan baik merupakan bentuk perwujudan pertanggungjawaban guru di sekolah, setelah diberikan penyadaran dari orang tua siswa. Guru juga bertanggungjawab atas kegiatan pembelajaran yang dilaksanakannya, sehingga secara komprehensif harus menanamkan berbagai macam pendidikan dalam pembelajarannya, termasuk kecintaan terhadap lingkungan sekitar, dengan cara mendaur ulang kertas untuk buku ajar. Untuk itulah diperlukan pemahaman secara baik terhadap limbah dan teknik montase, sehingga dapat meningkatkan buku ajar daur ulang yang berkualitas, sehingga berdampak positif terhadap peserta didik melalui model pembelajaran yang inovatif dan tidak membosankan. Hasil pengabdian tidak akan banyak bermanfaat bagi guru-guru, kecuali dilaksanakan melalui tindakan di kelas (praktik membuat buku ajar), dievaluasi, dan dilakukan perbaikan secara terus menerus, untuk menghasilkan buku ajar yang berkarakter baik. Oleh karena itu guru merasakan kebermanfaatan yang diperoleh dari pelatihan ini untuk meningkatkan pemahaman mengenai pembuatan buku ajar yang baik di sekolah dasar.

Para guru juga bertanggungjawab atas kelancaran kegiatan belajar mengajar dengan melibatkan peserta didik secara aktif, selain ilmu pendidikan, juga dapat 
dikembangkan sikap-sikap positif, untuk memberi keilmuan yang menunjang, dalam hal ini bidang pendidikan kepedulian lingkungan hidup. Pendampingan terhadap kajian dan evaluasi ketersediaan buku ajar dengan tampilan visual yang dilakukan, memberikan manfaat dalam bentuk nyata bagi guru, untuk menentukan solusi yang dapat diberdayakan, sehingga dapat membantu peserta didik di dalam kegiatan belajar mengajar.

Pelatihan pembuatan buku ajar berbasis limbah yang dijadikan materi pelatihan bertujuan utama agar guru mampu mengevaluasi kelayakan buku ajar, memberik variasi buku ajar, dan menciptakan media pembelajaran yang menyenangkan bagi peserta didik. Jika guru mampu memahami secara baik materi dan buku ajar yang tepat bagi sekolah dasar, tentu saja akan menambah keterampilan dan pengalaman untuk mendidik, serta menunjang profesi guru di masa-masa mendatang. Hal ini akan berdampak pada peningkatan penguasaan pengetahuandan keterampilannya sebagai seorang profesional. Selain itu, memberikan dampak positif akan terciptanya peserta didik yang berkualitas dan maju.

\section{SIMPULAN DAN SARAN}

Kegiatan pengabdian Pelatihan Pembuatan Buku Ajar Berbasis Limbah dengan Teknik Montase untuk guru-guru di GuguS Larasati Gunungpati Semarang dilaksanakan dengan baik. Peserta pelatihan tampak antusias mengikuti acara dan merasakan manfaat yang ditargetkan. Pelaksanaan pengabdian berhasil sampai tahap pemahaman terhadap materi kelayakan buku ajar yang diberikan, evaluasi buku ajar, dan membuat buku ajar dengan teknik montase. Keberhasilan ini ditunjukkan antara lain oleh:
1. Adanya kesepakatan untuk melaksanakan dan mengevaluasi buku ajar, sesuai dengan pengetahuan baru yang telah didapatkan untuk meningkatkan profesionalitas guru dan kemampuan siswa sekolah dasar.

2. Adanya respons yang positif dari peserta mengingat kegiatan pengabdian merupakan kebutuhan guru dalam rangka peningkatan kecintaan siswa terhadap pembelajaran di kelas.

3. Sebagian besar peserta memahami konsep penciptaan buku ajar berbasis limbah.

4. Pendidikan dan kepedulian terhadap pengelolaan limbah kertas secara baik, merupakan bagian penting dari pendidikan karakter untuk guru dan peserta didik di sekolah dasar.

\section{DAFTAR PUSTAKA}

Huda, Miftahul. 2014. Model-Model Pengajaran dan Pembelajaran. Yogyakarta: Pustaka Pelajar.

Setiawan, Deni, dkk. 2016. Pengetahuan Seni dan Gambar Ekspresi di Sekolah Dasar. Yogyakarta: AG Publishing.

Sukmana, Eis. Lestari, Rena, dan Karno, Ria. "Pengaruh Model Pembelajaran Langsung (Direct Instruction) Disertai Media Gambar Terhadap Hasil Belajar Biologi Siswa Kelas VII SMP Negeri 1 Tambusai Utara", dalam ejournal.upp.ac.id/index.php/fkipbio logi/article/download/ 588/521

Suprijono, Agus. 2015. Cooperatif Learning. Yogyakarta: Pustaka Belajar

Tarigan, Henry Guntur. 2008. Membaca sebagai Suatu Keterampilan Berbahasa. Bandung: Angkasa.

Tim Penyusun. 2015. Rencana Strategis 2015-2019 Lembaga Penelitian Dan 
Pengabdian Kepada Masyarakat Universitas Negeri Semarang. Semarang: LP2M UNNES.

Valjataga, Terje. Sebastian H. D. Fiedler. 2014. "Literature Review on Etextbooks". (Lecture Notes in Computer Science, Volume 8523; ISSN 0302- 9743). 
